\title{
EVALUATION OF BREAD WHEAT ADVANCED LINES UNDER SALINITY CONDITIONS USING TOLERANCE INDICES
}

\author{
Moustafa, Ehab S.A. \\ Plant Breeding Unit, Department of Genetic Resources, Desert Research \\ Center, El-Matareya, Cairo, Egypt \\ E-mail: ehab.soudi@yahoo.com
}

$\mathrm{T}$

his work focused on investigating the performance of thirteen newly wheat breeding lines compared with two check varieties under two salinity conditions; 6000 and $9000 \mathrm{ppm}$. The objectives were to determine salt-tolerant and sensitive genotypes using diverse tolerance indices. Additionally, to assess the genetic variability, heritability, genetic gain and genetic diversity among breeding lines using ISSR markers, protein electrophoresis and superoxide dismutase isozymes (SOD). The phenotypic and genotypic coefficients of variation displayed maximum values for number of spikes $/ \mathrm{m}^{2}$, grain yield and number of grains/spike. Seven tolerance indices were calculated; SSI, TOL, MP, GMP, STI, YI and YSI for all evaluated genotypes. The highest scores of all indices were registered by G10 followed by G3, G13, G7 and G1; on the contrary, the lowest values were recorded by G12, G8 and G5. Cluster analysis was performed based on tolerance indices and the genotypes were divided into four groups ranged from highly salt-tolerant to highly sensitive genotypes. ISSR-PCR analysis displayed 105 DNA fragments using 6 selected primers detected 77 polymorphic bands and 28 monomorphic bands. Protein electrophoresis revealed that the number of bands for all genotypes ranged from 11 to 14 with molecular weights ranged between 6 to $130 \mathrm{kDa}$ under salinity stress conditions. Unique bands of molecular weights 17 and $20 \mathrm{kDa}$ were detected just for G3 and G4. SOD patterns indicated more intensive bands for G3 and G4 under salinity stress.

Keywords: wheat, breeding lines, salinity, genetic variability, heritability, genetic gain

\section{INTRODUCTION}

There is a great demand to exploit salt-affected soils and saline irrigation water to meet the food requirements due to the continuous growing global population and shortage of fresh water (Varshney et al., 2011 and Turan et al., 2012). Water is the main factor that affects crop production (Gonzalez 
et al., 1999). Additionally, from a wide range of adverse factors, saline water is considered the most important factor that influences yield and crop adaptation to a particular environment (Mansour et al., 2020). Unesco Water Portal (2005) and FAO (2008) reported that $6 \%$ of the worlds' total land and $20 \%$ of irrigated areas are affected by salinity and about 80 countries are semiarid. Developing salt-tolerant genotypes has been proposed as the most effective way to reduce the deleterious effects of salinity on crop production (El-Hendawy et al., 2011). Using natural saline water with different levels of salinity is an important option for agricultural production in arid and semi-arid regions to face depletion and shortage of fresh water.

Plant response to salt stress is a complex phenomenon that involves changes in plant morphology and physiology (Munns, 2005). Various mechanisms are generated in plants under salinity as accumulation of ions into different tissue compartments; production of osmolytes, protein denaturation; production of enzymatic and non-enzymatic antioxidants, acceleration of lipid peroxidation, DNA damage and inhibition of photosynthesis (Shao et al., 2007). Otherwise, plant response to salinity stress differs according to species, genotype and developmental stage (Turan and Tripathy, 2012). Evidently, only a few crop species and genotypes are adapted to salinity conditions (Mohamed et al., 2007).

Developing high-yielding and salt-tolerant genotypes is the main objective of plant breeders. Certainly, breeding materials are crucial for enhancing tolerance against adverse conditions. Investigating the genotypic variation among available breeding materials and their response to environmental stress is essential to develop new tolerant genotypes (Mitra, 2001). Moreover, studying the genetic behavior of different agronomic traits could contribute to better understanding the adaptability and possibility of improving grain yield under stress conditions (Limin et al., 2007). Furthermore, the recent molecular analysis leads to the feasibility of inheritance of qualitative and quantitative traits. Besides, molecular approaches enhance the identification of genes controlling important traits and evaluate their contribution to phenotypic performance which facilitates selecting favorable alleles using marker-assisted selection (Turan et al., 2012).

Wheat (Triticum aestivum) is the most widely potential valuable food all over the world that provides more calories and protein than any other food crop (Hanson et al., 1982). It is the most broadly grown crop in the world, its production area in 2019 was 215.9 million hectares produced 765.8 million tons (FAOSTAT, 2021). The worlds' food demands increase annually and require national and international strategies to fill the gap between its consumption and production despite the shortage of water resources and agricultural areas. Moreover, global water reduction is expected to become a

Egyptian J. Desert Res., 71, No. 1, 23-52 (2021) 
serious problem by the year 2025, especially in areas with high population density (Cosgrove and Rijsberman, 2000).

Developing high-yielding genotypes based on their performance is helpful for improving wheat yield under different stresses (Saidi et al., 2000). Estimating the magnitude of phenotypic and genotypic variability, heritability and genetic gain is crucial to optimize the selection process of the breeding program. Heritability quantifies the expected improvement depending upon selection and explains the cause of observed differences among genotypes whether genetically or environmentally. Expected genetic gain gives an idea about the possible improvement through advanced generations by selecting high performing genotypes. Additionally, heritability coupled with genetic gain is better than estimating heritability alone to predict the amount of genetic improvement that could be achieved by selecting high performing genotypes (Abdel-Ghani, 2013).

There are several tolerance indices that could be used to identify tolerant or sensitive genotypes to environmental stresses. Tolerance index (TOL) is defined as the differences in yield between stress and non-stress environments, mean productivity (MP) is yield average of genotypes under stress and non-stress conditions, stress susceptibility index (SSI) is used for investigating yield stability in variable environments, geometric mean productivity (GMP) is used interested of relative performance, stress tolerance index (STI) is used to determine tolerance potential of the evaluated genotypes, harmonic mean (HM) is utilized to evaluate genotype stability under both stress and non-stress conditions and superiority index (Pi) is used as an indicator to compare the productivity of genotypes across different environments and identify superiority of genotypes (Huang, 2000; Golabadi et al., 2006; Jafari et al., 2009; Akcura and Ceri, 2011). Moghaddam and HadiZadeh (2002) reported that STI is useful to select favorable cultivars under stressful and non-stressful conditions. Khalili et al. (2004) showed that maize hybrids with high yield under both stress and non-stress environments can be selected using GMP and STI indices. Akcura et al. (2011) indicated that the tolerance indices; SSI, MP, GMP, TOL, HM and STI are useful indicators for wheat breeding under stress conditions. Firozi et al. (2012) displayed that MP and STI significantly correlate with grain yield under both stress and nonstress conditions and these indices able to discriminate tolerant and sensitive genotypes. Ilyas-Khokhar et al. (2012) suggested that breeders can select better genotypes using tolerance indices GMP, MP, STI and YI under stress conditions and compare results with performance under non-stressed conditions.

The present study aimed at focusing on attaining a further improvement in wheat adaptability by selecting salt-tolerant genotypes through their performance. Moreover, determining certain indices with 
variability, heritability and genetic gain estimations. Besides assessing the genetic diversity relationships among thirteen newly wheat breeding lines selected under salinity stress using ISSR markers, protein electrophoresis and superoxide dismutase isozymes.

\section{MATERIALS AND METHODS}

\section{Experimental Site and Agricultural Practices}

Two field experiments were carried out at the Experimental Farm of Desert Research Center, Ras-Sudr Research Station, South Sinai, Egypt $\left(29^{\circ}\right.$ $35^{\prime} \mathrm{N}, 32^{\circ} 41^{\prime} \mathrm{E}$ ) using saline water for irrigation at levels of 6000 and 9000 ppm during 2017/2018 and 2018/2019 growing seasons. The breeding materials were thirteen wheat breeding lines were obtained from Wheat Breeding Program, Plant Breeding Unit of Genetic Resources Department of Desert Research Center, Mataria, Egypt in addition to two adapted check varieties (Table 1). The experiments were performed using Randomized Complete Block Design (RCBD) with three replicates. Each genotype was sown in five rows of $2-\mathrm{m}$ length and $0.25-\mathrm{m}$ apart. All other agricultural practices were applied according to the recommendations in the study region. The irrigated water was used from two different wells and was analyzed as illustrated in Table (2).

\section{Measured Traits}

The recorded agronomic traits in this study were days to heading, plant height $(\mathrm{cm})$, number of spikelets/spike, spike length, number of spike $/ \mathrm{m}^{2}$, number of grains/spike, 1000-grain weight (g) and grain yield/fad.

\section{ISSR-PCR Technique}

Fresh leaves were collected from all genotypes after 45 days from sowing and ground into fine powder using liquid nitrogen and kept frozen in $-80^{\circ} \mathrm{C}$ till tested for ISSR, electrophoretic pattern of proteins and isozymes. Genomic DNAs were extracted from frozen tissue of individual samples following the procedure described by DNeasy Plant Mini Kit (Qiagen Inc., Cat. no. 69104, USA). The concentration and quality of genomic DNA samples were estimated on spectrophotometer ND-2000 (Nanodrop, USA). Finally, all genomic DNA samples were diluted to a final concentration of 40 $\mathrm{ng} / \mu \mathrm{l}$ with TE buffer (10 mM TrisHC1, $\mathrm{pH} 8.0 ; 1 \mathrm{mM}$ EDTA) and stored at $20^{\circ} \mathrm{C}$ for further use. A set of 6 primers ISSR was used in the detection of polymorphism (Table 3 ). The amplification reaction was carried out in $25 \mu \mathrm{l}$ reaction volume containing $1 \mathrm{X}$ PCR buffer, $1.5 \mathrm{mM} \mathrm{MgCl}_{2}, 0.2 \mathrm{mM}$ dNTPs, $1 \mu \mathrm{M}$ primer, $1 \mathrm{U}$ Taq DNA polymerase and $30 \mathrm{ng}$ template DNA. PCR programmed to fulfill 35 cycles after an initial denaturation cycle for $5 \mathrm{~min}$ at

Egyptian J. Desert Res., 71, No. 1, 23-52 (2021) 
$94^{\circ} \mathrm{C}$. Each cycle consisted of a denaturation step at $94^{\circ} \mathrm{C}$ for $1 \mathrm{~min}$, an annealing step at $50^{\circ} \mathrm{C}$ for $1 \mathrm{~min}$, and an elongation step at $72^{\circ} \mathrm{C}$ for $1.5 \mathrm{~min}$. The primer extension segment was extended to $7 \mathrm{~min}$ at $72^{\circ} \mathrm{C}$ in the final cycle. The amplification products were resolved by electrophoresis in a $1.5 \%$ agarose gel containing ethidium bromide $(0.5 \mathrm{ug} / \mathrm{ml})$ in $1 \mathrm{X}$ TAE buffer at 95 volts. A 100 bp DNA ladder was used as DNA standard size marker. PCR products were visualized on UV light and photographed using a Gel Documentation System (BIO-RAD 2000).

Table (1). Code, origin and pedigree of the used wheat genotypes.

\begin{tabular}{|c|c|c|}
\hline Genotypes & Name & Pedigree \\
\hline Parents & & \\
\hline $\mathrm{C} 1$ & Giza168 & MIL/BUC//Seri CM 93046-8M-04-0M-2Y-0B-062 \\
\hline $\mathrm{C} 2$ & Acsad903 & $\begin{array}{c}\text { ACSAD52914/C18224/C1683/3/Cno*2/7c//TopAcs- } \\
\text { W-8024-20IZ-3IZ-4IZ-0IZ }\end{array}$ \\
\hline $\mathrm{C} 3$ & Acsad949 & SNB,S,ASAD30SATS-W-8083-3IZ-5IZ-3IZ-0IZ \\
\hline $\mathrm{C} 4$ & Line1 & TEVEE-I/SHUHA-C6 \\
\hline $\mathrm{C} 5$ & Line63 & CHAM-4/GRU90-202579 \\
\hline C6 & Cham6 & CM39992-2M-7Y-0M-OAP \\
\hline $\mathrm{C} 7$ & V4 & Azeghar-2/3/Mrf2//Bcr/Gro1 \\
\hline $\mathrm{C} 8$ & V11 & Bcr/Gro1//Mgnl1 \\
\hline $\mathrm{C} 10$ & Gemaiza7 & CMH74 A. $630 / 5 \mathrm{x} / /$ Seri $82 / 3 /$ Agent \\
\hline
\end{tabular}

\section{Lines}

\begin{tabular}{llc} 
L1 & G1 & $\mathrm{C} 5 \times \mathrm{C} 2$ \\
L2 & G2 & $\mathrm{C} 5 \times \mathrm{C} 2$ \\
L3 & G3 & $\mathrm{C} 4 \times \mathrm{C} 6$ \\
L4 & G4 & $\mathrm{C} 4 \times \mathrm{C} 6$ \\
L5 & G5 & $\mathrm{C} 9 \times \mathrm{C} 10$ \\
L6 & G6 & $\mathrm{C} 10 \times \mathrm{C} 7$ \\
L7 & G7 & $\mathrm{C} 8 \times \mathrm{C} 10$ \\
L8 & G8 & $\mathrm{C} 4 \times \mathrm{C} 6$ \\
L9 & G9 & $\mathrm{C} 1 \times \mathrm{C} 3$ \\
L10 & G10 & $\mathrm{C} 8 \times \mathrm{C} 10$ \\
L11 & G11 & $\mathrm{C} 10 \times \mathrm{C} 7$ \\
L12 & G12 & $\mathrm{C} 10 \times \mathrm{C} 7$ \\
L13 & G13 & $\mathrm{C} 1 \times \mathrm{C} 2$ \\
\hline
\end{tabular}

\section{Check varieties}

Misr 1 G14 OASIS/SKAUZ//4*BCN/3/2*PASTOR.

Sakha 93 G15 Sakha 92/TR 810328 S 8871-1S-2S-1S-0S

Egyptian J. Desert Res., 71, No. 1, 23-52 (2021) 
Table (2). Water and soil chemical analysis.

\begin{tabular}{|c|c|c|c|c|c|c|c|c|c|c|}
\hline \multirow{2}{*}{ Level } & \multirow{2}{*}{ pH } & \multirow{2}{*}{$\begin{array}{c}\text { EC } \\
\text { ppm }\end{array}$} & \multicolumn{4}{|c|}{ Cations (meq/l) } & \multicolumn{4}{|c|}{ Anions (meq/l) } \\
\hline & & & $\mathbf{C a}^{++}$ & $\mathbf{M g}^{++}$ & $\mathrm{Na}^{+}$ & $\mathbf{K}^{+}$ & $\mathrm{CO}_{3}{ }^{-}$ & $\mathrm{HCO}_{3}^{-}$ & $\mathrm{Cl}^{-}$ & $\mathrm{SO}_{4}{ }^{--}$ \\
\hline \multicolumn{11}{|c|}{ Water analysis } \\
\hline Well 1 & 7.82 & 5557 & 10.8 & 7.15 & 53.6 & 0.35 & - & 5.30 & 39.1 & 26.8 \\
\hline Well 2 & 7.66 & 8934 & 19.3 & 13.8 & 105.1 & 0.90 & - & 7.50 & 93.1 & 38.7 \\
\hline \multicolumn{11}{|c|}{ Soil analysis } \\
\hline Soil & 7.76 & 6195 & 4.6 & 3.2 & 88.3 & 0.67 & - & 4.95 & 65.7 & 26.1 \\
\hline
\end{tabular}

Table (3). Selected ISSR primers for polymorphic DNA generation were used for thirteen bread wheat genotypes.

\begin{tabular}{lc}
\hline Name Primer & Sequence \\
\hline ISSR- 2 & 5'-AGAGAGAGAGAGAGAGYG-3' \\
ISSR- 8 & 5'-AGACAGACAGACAGACGC-3' \\
ISSR- 10 & 5'-GACAGACAGACAGACAAT-3' \\
ISSR- 11 & 5'-ACACACACACACACACYA-3' \\
ISSR- 13 & 5'-AGAGAGAGAGAGAGAGYT-3' \\
ISSR- 14 & 5'-CTCCTCCTCCTCCTCTT-3' \\
\hline
\end{tabular}

\section{Statistical Analysis}

Data of all traits were subjected to analysis of variance according to Lydansky (1988). Phenotypic and genotypic variances and broad-sense heritability were estimated according to Singh and Chaudhary (1985). The genetic gain $(\mathrm{GG})$ as a percentage of respective checks was computed using the formula developed by St. Martin and McClain (1991). Salinity tolerance indices were calculated as following equations: Stress susceptibility index $(\mathrm{SSI})=(1-\mathrm{Ys} / \mathrm{Yp}) / \mathrm{SI}$ where SI $($ Stress intensity $)=1-\mathrm{Ysi} / \mathrm{Ypi}$ (Fischer and Maurer, 1978), Tolerance index $(\mathrm{TOL})=\mathrm{Yp}-\mathrm{Ys}$ (Rosielle and Hamblin, 1981), Mean productivity $(\mathrm{MP})=(\mathrm{Yp}+\mathrm{Ys}) / 2$ (Rosielle and Hamblin, 1981),

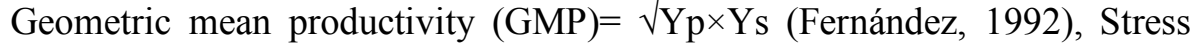
tolerance index $(\mathrm{STI})=(\mathrm{Yp} \times \mathrm{Ys}) / \mathrm{Ypi}^{2}($ Fernández, 1992), Yield index $(\mathrm{YI})$ $=$ Ys/Ysi (Gavuzzi et al., 1997), Yield stability index $(Y S I)=Y s / Y p$ (Bouslama and Schapaugh, 1984), where: Ys is the yield of genotype under stress condition; Yp the yield of genotype under normal condition; while Ysi and Ypi are the total mean yields of all genotypes under stress and normal conditions, respectively. Cluster analysis was performed using Ward's method (Kumar et al., 2009). All the statistical analyses were performed using SPSS v 16.0 (SPSS Inc., 2007, Chicago, IL, USA) software program. 


\section{ISSR-PCR Analysis}

Banding patterns generated by ISSR-PCR markers were compared to determine the genetic similarity of the evaluated genotypes. Clear and distinct amplification products were scored as ' 1 ' for the presence and ' 0 ' for the absence of bands. Bands of the same mobility were scored as identical. The genetic similarity coefficient (GS) between two genotypes was estimated according to Dice coefficient (Sneath and Sokal, 1973). The similarity matrix was used in the cluster analysis that was employed to organize the observed data into meaningful structures to develop taxonomies. At the first step, when each accession represents its own cluster, the distances between these accessions are defined by the chosen distance measure (Dice coefficient). However, once several accessions have been linked together, the distance between two clusters is calculated as the average distance between all pairs of accessions in the two different clusters and this is called Unweighted Pair Group Method using Arithmetic Average (UPGMA) (Sneath and Sokal, 1973).

\section{Electrophoretic Pattern of Proteins and Superoxide Dismutase Isozyme}

Soluble proteins in leaves were determined according to SDS-PAGE gel electrophoresis using acrylamide slab gels following the system of Laemmli (1970). While superoxide dismutase (SOD) was extracted from plant samples and separated by native polyacrylamide gel electrophoresis (PAGE) according to Weydert and Cullen (2010).

\section{RESULTS AND DISCUSSION}

The genetic variations within and between populations can be induced by recombination, mutations, and introgressions (Hawkes, 2013). These variations could be used in breeding to increase the possibilities of developing new highly productive cultivars with good quality properties (Horsley et al., 1995 and Bockelman et al., 2010). The statistical parameters; mean performance, genetic variability, heritability and genetic gain are vital to evaluate the performance and genetic stability of any derived genotypes and efficient selection of particular traits (Firouzian, 2003).

\section{Analysis of Variance}

The analysis of variance displayed highly significant differences between the two salinity levels and among the evaluated genotypes for all traits (Table 4). These findings confirm the presence of genetic variability in studied genotypes as well as salinity levels. The magnitude of mean squares indicates that the measured traits were highly affected by salinity than 


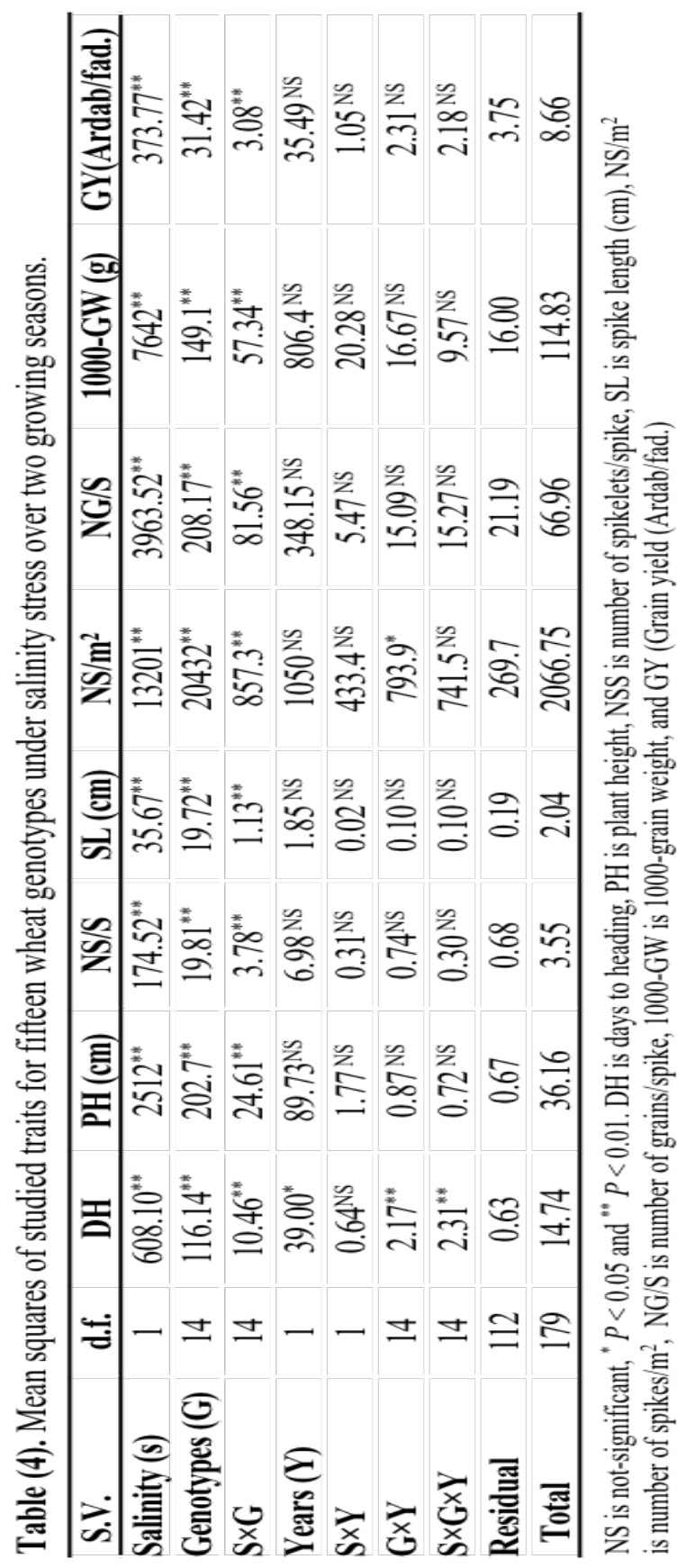

Egyptian J. Desert Res., 71, No. 1, 23-52 (2021) 
genotype. Although the interaction between salinity and genotypes showed lower magnitude than the main effects of salinity and genotype, it was significant for all traits which indicates that the genotypes behaved differently under different salinity levels. While the three-way interaction among salinity, genotype and year was non-significant for most studied traits. These results were in accordance with those of Balkan (2018), Jaur (2019), Khanzada et al. (2019), Mishra et al. (2019), Shah et al. (2019), Al-Naggar et al. (2020), Bayisa et al. (2020), Ferede and Worede (2020), Gadimaliyeva et al. (2020) and Nizamani et al. (2020).

\section{Mean Performance}

Increasing salinity level resulted in significant earliness in heading for all wheat genotypes. The earliest heading was recorded by the genotypes G14, G1, G4, G10 and G3 while the late heading was obtained by G8, G12, G5 and G7 under the two salinity levels (Fig. 1A). Earliness in heading could be considered as an important strategy and resilient adaptation to face environmental stress (Shavrukov et al., 2017). Likewise, plant height declined significantly from 94.17 to $60.50 \mathrm{~cm}$ as a result of increasing salinity level from 6000 to $9000 \mathrm{ppm}$ (Fig. 1B). The shortest plants were recorded by G12, G3, G9 and G14, while the tallest plants were obtained by G1, G13, G4 and G7 under two salinity levels. Spike length significantly affected by salinity stress and reduced from $15.77 \mathrm{~cm}$ at low salinity level $(6000 \mathrm{ppm})$ to $10 \mathrm{~cm}$ at high salinity (9000 ppm) level (Fig. 1C). The genotypes; G1, G12 and G6 showed the longest spike under low salinity level while shortest spikes were assigned for G10, G3, G14 and G2 under high salinity level.

Number of spikelets/spike scientifically reduced under high salinity (9000 ppm) level. The genotypes G3 and G2 exhibited the lowest number of spikelets, while the highest values were recorded by G6 and G1 under low salinity $(6000 \mathrm{ppm})$ level (Fig. 2A). Likewise, number of spikes $/ \mathrm{m}^{2}$ was affected by salinity elevation and decreased gradually under salinity levels (Fig. 2B). The genotypes G10, G1 and G3 displayed the highest values, while G8, G12 and G4 exhibited the lowest values under both salinity levels. Number of grains/spike was declined from 61 to 36.96 grains by increasing salinity from 6000 to $9000 \mathrm{ppm}$. The genotypes G2 and G13 displayed the fewest number while G9, G8 and G6 produced the highest values under both salinity levels (Fig. 2C).

The weight of 1000-grain performed differently under salinity levels, its values decreased from $59.9 \mathrm{~g}$ under low salinity level to $32 \mathrm{~g}$ under high salinity level. The heaviest weight was signed at low salinity level by G7, G5, G3 and G11, while lighter grains were recorded by G6, G12, G10 and G7 under high salinity level (Fig. 3A). Finally, increasing salinity level led to a significant reduction in grain yield (Fig. 3B) from 14.25 under low level to 
$5.43 \mathrm{ardab} /$ fad under high salinity level. The highest grain yield was obtained by G10, G7 and G3, while the lowest values were assigned for G12, G5, G13 and G8 under both levels. The obtained results are compatible with those of Salah et al. (2005), Awaad et al. (2010), Asgari et al. (2011), Maryam et al. (2012), Sonia et al. (2013), Al-Naggar et al. (2015), Sara et al. (2015), Afiah et al. (2016) and Abbas et al. (2018).
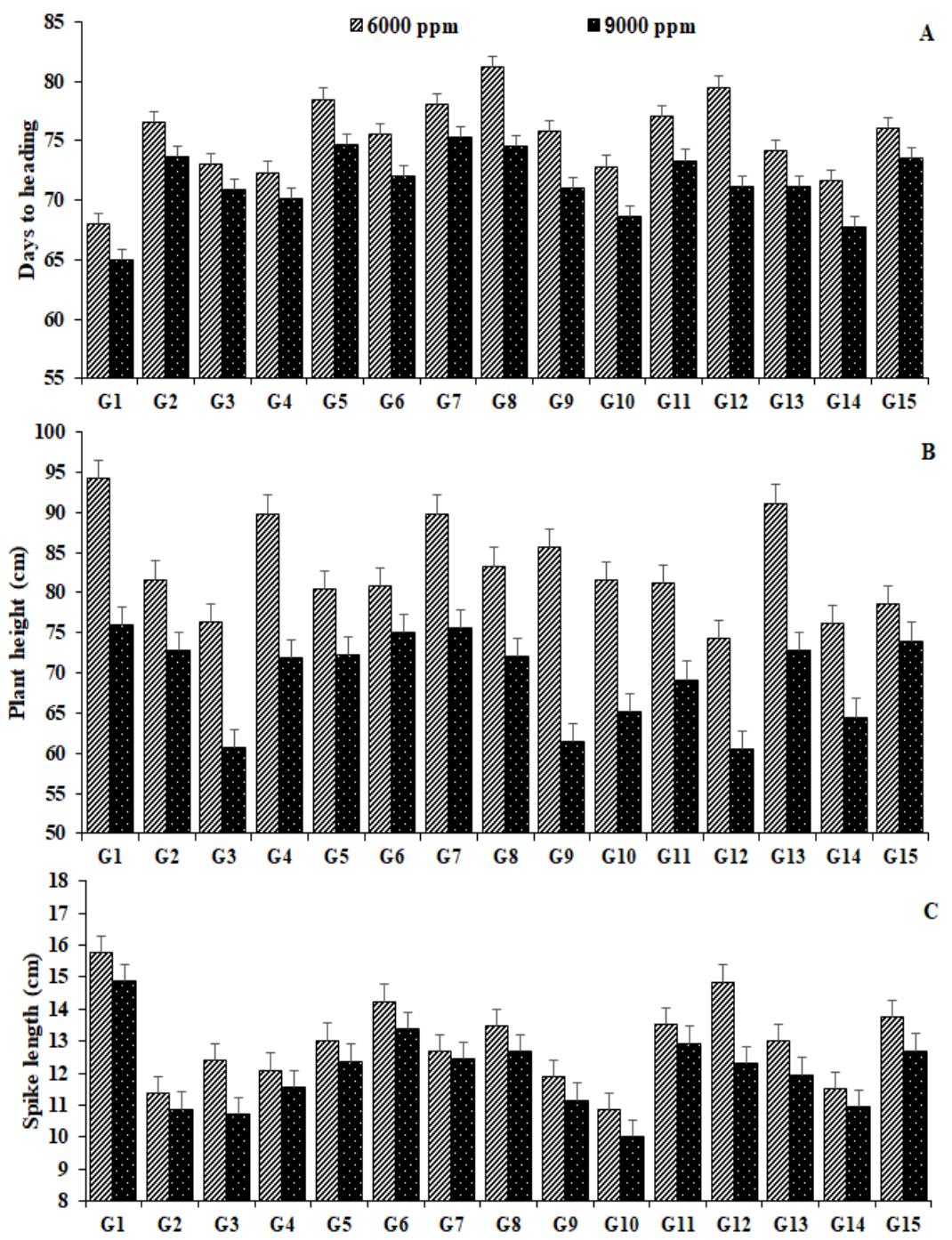

Fig. (1). Impact of salinity stress on days to heading (A), plant height (B) and spike length $(\mathrm{C})$ for fifteen wheat genotypes.

Egyptian J. Desert Res., 71, No. 1, 23-52 (2021) 

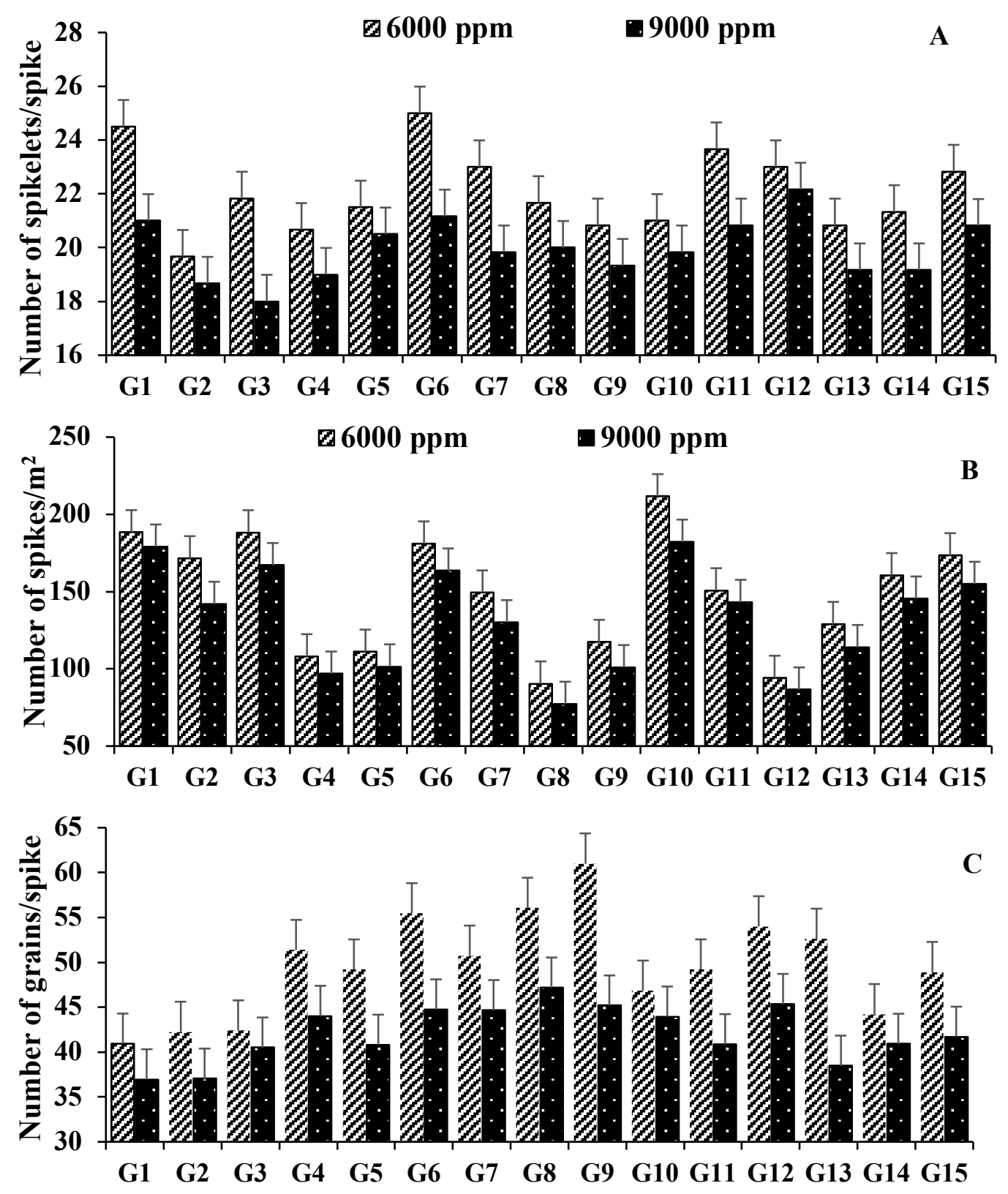

Fig. (2.) Impact of salinity stress on number of spikelets/ spike (A), number of spikes $/ \mathrm{m}^{2}$ (B), number of grains/spike (C) for fifteen wheat genotypes. 

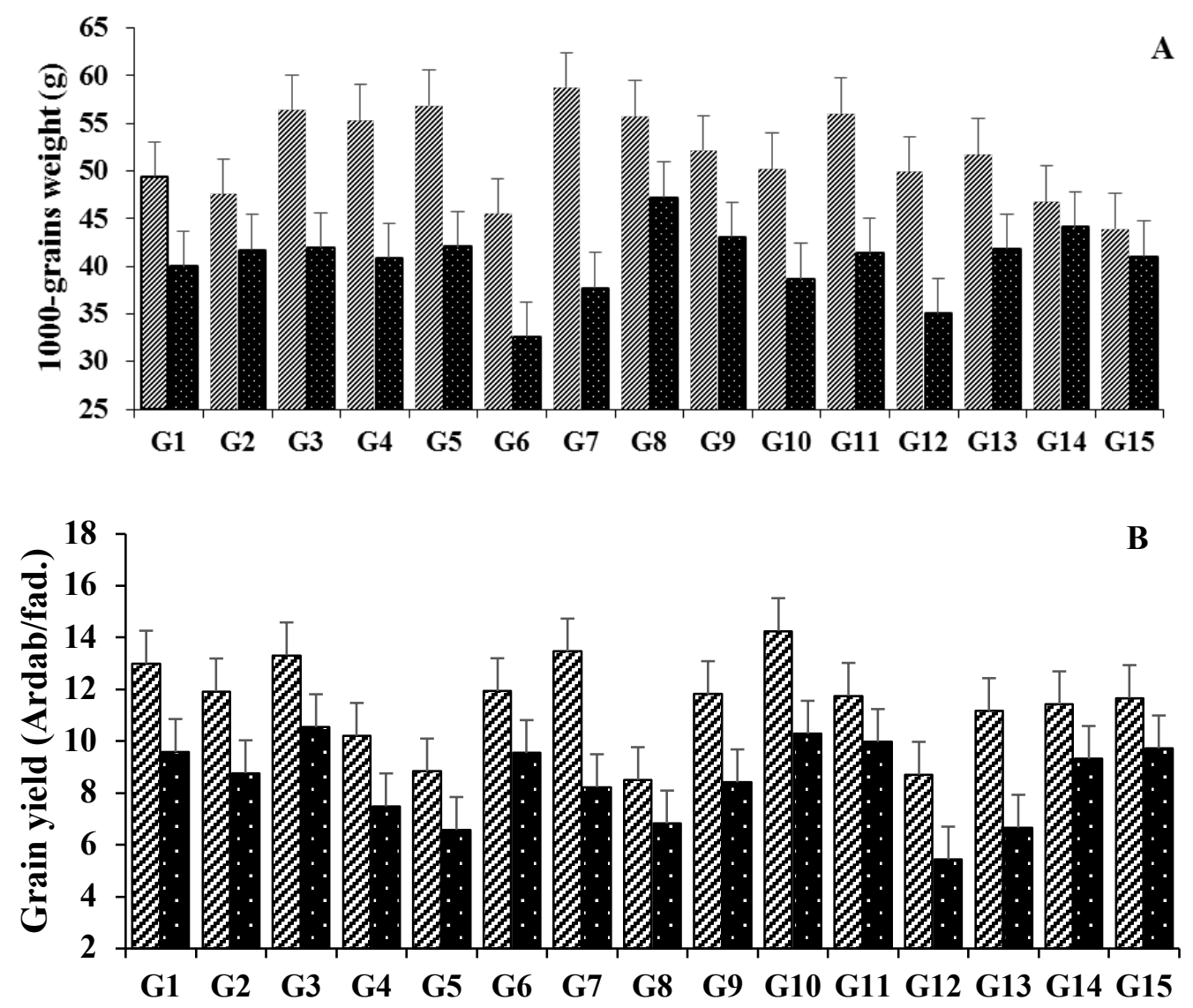

Fig. (3). Impact of salinity stress on 1000-grain weight (A) and grain yield (B) for fifteen wheat genotypes.

\section{Genetic Variability, Heritability and Genetic Gain}

The highest genetic variations were assigned for number of spikes $/ \mathrm{m}^{2}$, grain yield and number of grains/spike (Table 5). On the other hand, spike length, 1000-grain weight and plant height displayed intermediate values, and days to heading and number of spikelets/spike presented low values under two salinity levels. Phenotypic coefficient values (PCV) were relatively higher in its magnitudes than the genotypic one (GCV) for all traits with smaller differences between them. These variations revealed to low environmental effect on the expression of the evaluated trait. These findings confirmed that selection can be effective using these traits and their phenotypic expression is a good indication for genetic potential. Many authors reported similar Egyptian J. Desert Res., 71, No. 1, 23-52 (2021) 
conclusions as Balkan (2018), Jaur (2019), Khanzada et al. (2019), Mishra et al. (2019), Shah et al. (2019), Al-Naggar et al. (2020), Bayisa et al. (2020), Ferede and Worede (2020) and Nizamani et al. (2020).

Table (5). Genetic variability parameters for the studied traits in fifteen wheat genotypes under salinity stress over two growing seasons.

\begin{tabular}{lcccccccc}
\hline Trait & Salinity & $\boldsymbol{\sigma}^{\mathbf{2}} \mathbf{P}$ & $\boldsymbol{\sigma}^{\mathbf{2}} \mathbf{G}$ & $\boldsymbol{\sigma}^{\mathbf{2}} \mathbf{E}$ & $\mathbf{P . C . V}$ & $\mathbf{G . C . V}$. & $\mathbf{h}^{\mathbf{2}} \mathbf{b}$ & $\mathbf{G . G}$. \\
\hline Days to & 6000 & 13.11 & 12.33 & 0.78 & 4.79 & 4.65 & 94.07 & 7.02 \\
heading & 9000 & 8.74 & 7.95 & 0.79 & 4.12 & 3.93 & 90.88 & 5.54 \\
\hline \multirow{2}{*}{ Plant height } & 6000 & 54.58 & 30.40 & 24.18 & 8.82 & 6.57 & 55.61 & 8.48 \\
& 9000 & 87.57 & 42.34 & 45.23 & 13.61 & 9.46 & 48.60 & 9.35 \\
\hline No. & 6000 & 3.06 & 2.44 & 0.62 & 7.92 & 7.07 & 79.86 & 2.88 \\
spikelets/spi & 9000 & 1.87 & 1.14 & 0.73 & 6.85 & 5.33 & 61.25 & 1.73 \\
\hline \multirow{2}{*}{ Spike length } & 6000 & 2.03 & 1.88 & 0.15 & 10.94 & 10.53 & 92.70 & 2.72 \\
& 9000 & 1.75 & 1.59 & 0.16 & 10.94 & 10.42 & 90.78 & 2.48 \\
\hline \multirow{2}{*}{ No. spike/m ${ }^{2}$} & 6000 & 2614 & 2305 & 309.1 & 34.57 & 32.48 & 88.25 & 92.88 \\
& 9000 & 1416 & 1216 & 200.3 & 29.05 & 26.91 & 85.79 & 66.59 \\
\hline \multirow{2}{*}{ go. } & 6000 & 50.31 & 27.55 & 22.76 & 13.54 & 9.98 & 54.17 & 7.89 \\
\multirow{2}{*}{ 1000 GW } & 9000 & 31.01 & 11.25 & 19.76 & 13.31 & 7.96 & 35.71 & 4.12 \\
\hline \multirow{2}{*}{ Grain yield } & 6000 & 24.90 & 12.91 & 11.99 & 9.32 & 6.67 & 51.94 & 5.34 \\
& 9000 & 32.21 & 12.42 & 19.79 & 14.11 & 8.87 & 43.11 & 4.67 \\
\hline
\end{tabular}

$\sigma^{2} \mathrm{~g}$ is genotypic variance, $\sigma^{2} \mathrm{p}$ is phenotypic variance, $\sigma^{2} \mathrm{E}$ is environmental variance, GCV genotypic coefficient of variation, $\mathrm{PCV}$ is phenotypic coefficient of variation, $\mathrm{h}_{\mathrm{b}}^{2}$ is heritability in broad sense and G.G. is genetic gain.

\section{Salinity Tolerance Indices and Cluster Analysis}

Seven tolerance indices were calculated; SSI, TOL, MP, GMP, STI, YI and YSI (Table 6). These indices were effective to identify tolerant and sensitive genotypes to salt stress. The highest values were assigned for G10 followed by G3, G13, G7 and G1 indicating their high tolerance to salinity stress. On the other hand, the most sensitive genotypes were G12 followed by G8 and G5 since they showed the lowest values. Cluster analysis was performed based on tolerance indices and the genotypes were classified into four groups (Fig. 4). Group A included two genotypes; G10 and G3 which had the highest values of tolerance indices, hence, they could be considered highly salt-tolerant and most desirable genotypes. Group B comprised of eight genotypes G7, G2, G9, G1, G14, G11, G6 and G15 which possessed also intermediate values, therefore, they could be considered as moderate salt- 
tolerant genotypes. Group C contained two genotypes G4 and G13 that had low values, which could be considered sensitive genotypes. Finally, Group D consisted of three genotypes G12, G8 and G5 that displayed the lowest values and subsequently these genotypes could be considered the highly sensitive ones. These results were in consistence with those of Bagci et al. (2007), Ahmadi et al. (2012), Asadi et al. (2012), Badran and Moustafa (2014), Abd El-Mohsen et al. (2015); Desheva and Kyosov (2015), Sanjay et al. (2015), Sara et al. (2015), Afiah et al. (2016), Darwish et al. (2017), Maha et al. (2017), Yassin, et al. (2019) and Gadimaliyeva et al. (2020).

Table 6. Salinity tolerance indices for fifteen wheat genotypes under salinity stress 6000 and $9000 \mathrm{ppm}$ (averaged over the two growing seasons).

\begin{tabular}{lccccccccc}
\hline Genotypes & Yp & Ys & SSI & TOL & MP & GMP & STI & YI & YSI \\
\hline G1 & 13.00 & 9.59 & 1.01 & 3.41 & 11.29 & 11.16 & 0.95 & 1.13 & 0.74 \\
G2 & 11.92 & 8.77 & 1.02 & 3.16 & 10.34 & 10.22 & 0.80 & 1.03 & 0.74 \\
G3 & 13.32 & 10.54 & 0.80 & 2.77 & 11.93 & 11.85 & 1.07 & 1.24 & 0.79 \\
G4 & 10.21 & 7.49 & 1.03 & 2.72 & 8.85 & 8.74 & 0.58 & 0.88 & 0.73 \\
G5 & 8.83 & 6.58 & 0.98 & 2.26 & 7.70 & 7.62 & 0.44 & 0.77 & 0.74 \\
G6 & 11.93 & 9.55 & 0.77 & 2.39 & 10.74 & 10.67 & 0.87 & 1.12 & 0.80 \\
G7 & 13.46 & 8.23 & 1.50 & 5.24 & 10.85 & 10.52 & 0.84 & 0.97 & 0.61 \\
G8 & 8.50 & 6.83 & 0.76 & 1.67 & 7.66 & 7.62 & 0.44 & 0.80 & 0.80 \\
G9 & 11.82 & 8.41 & 1.11 & 3.40 & 10.12 & 9.97 & 0.76 & 0.99 & 0.71 \\
G10 & 14.25 & 10.29 & 1.07 & 3.96 & 12.27 & 12.11 & 1.12 & 1.21 & 0.72 \\
G11 & 11.75 & 9.97 & 0.58 & 1.78 & 10.86 & 10.83 & 0.89 & 1.17 & 0.85 \\
G12 & 8.71 & 5.43 & 1.45 & 3.27 & 7.07 & 6.88 & 0.36 & 0.64 & 0.62 \\
G13 & 11.16 & 6.66 & 1.55 & 4.50 & 8.91 & 8.62 & 0.57 & 0.78 & 0.60 \\
G14 & 11.43 & 9.32 & 0.71 & 2.11 & 10.37 & 10.32 & 0.81 & 1.10 & 0.82 \\
G15 & 11.67 & 9.72 & 0.64 & 1.94 & 10.70 & 10.65 & 0.86 & 1.15 & 0.83 \\
\hline \multicolumn{1}{l}{ Yp is grain yield under 6000 ppm, Ys is grain yield under 9000 ppm, SSI is stress sensitivity } \\
index, MP is mean productivity, GMP is geometric mean productivity, STI is stress tolerance \\
index, YI is yield index and YSI is yield stability index.
\end{tabular}

Egyptian J. Desert Res., 71, No. 1, 23-52 (2021) 


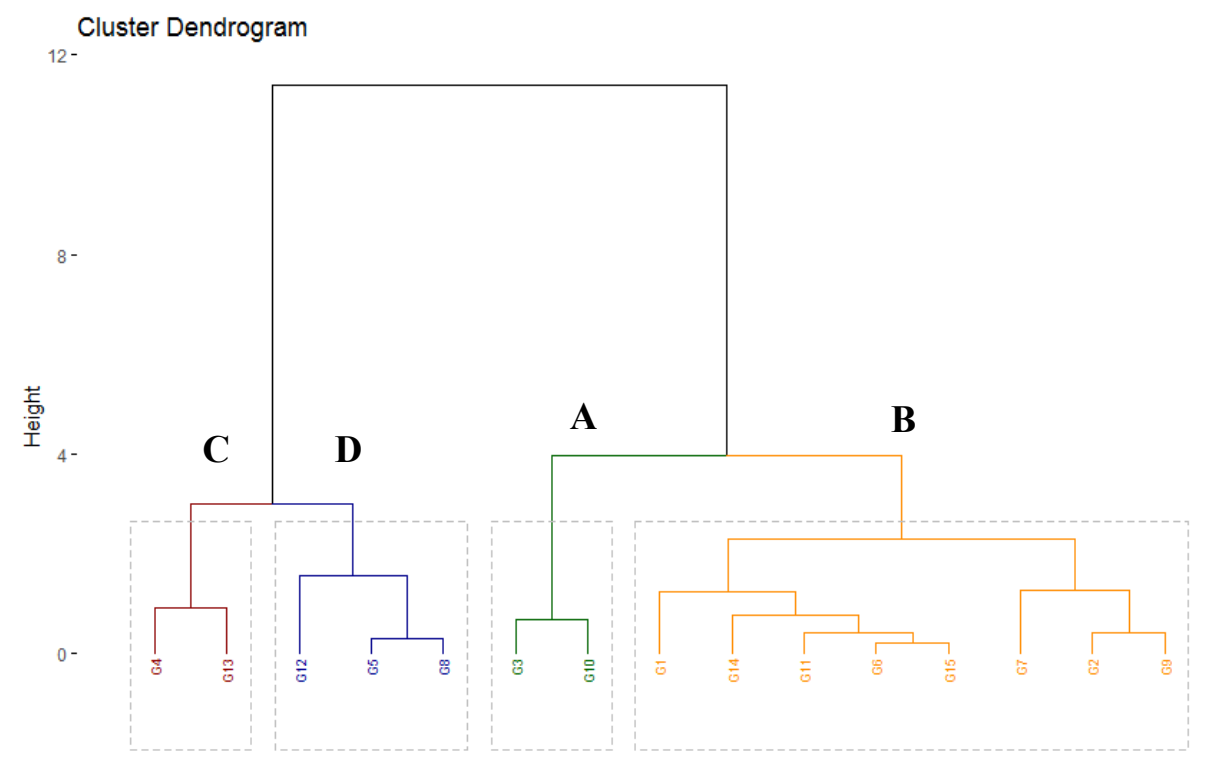

Fig. (4). Dendogram of the distances among fifteen wheat genotypes under salinity stress; 6000 and $9000 \mathrm{ppm}$. The genotypes were classified into four groups; A is salt-tolerant (two genotypes), B is moderate salinity-tolerant (eight genotypes), $\mathrm{C}$ is salinity-sensitive (two genotypes) and D is highly salt-sensitive (three genotypes).

\section{ISSR Markers for Salinity Tolerance in Wheat Genotypes}

Six ISSR primers were used to study the genetic diversity and relationships among tested thirteen breeding lines by exploring amplification products and polymorphic fingerprint patterns. A total of 105 DNA fragments were detected contained 77 polymorphic and 28 monomorphic bands (Fig. 5 and Table 7) with an average of 17.5 bands per primer. The number of polymorphic bands was calculated (ranged from $29 \%$ to $92 \%$ with an average of $69 \%$ ) to determine the polymorphism degree. On the other hand, the most polymorphic amplified DNA bands ranged from 130 to 1500 base pairs (bp) in size primer ISSR-2. Primer ISSR-10 exhibited the lowest number of amplified polymorphic fragments (4). The band frequency mean was 0.4 (ISSR-2 and ISSR-13) to 0.8 (ISSR-10) with 0.55 as average values. 

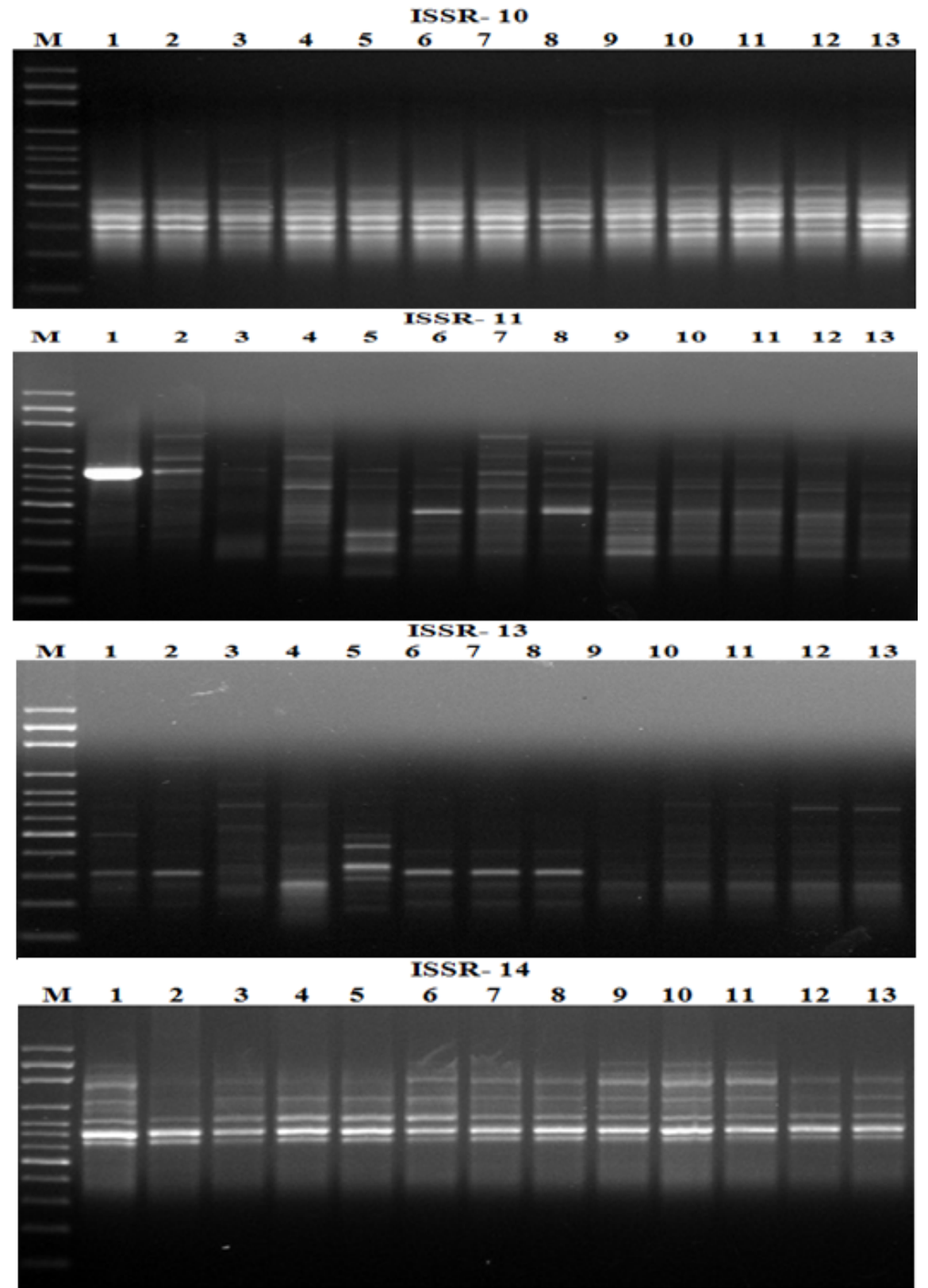

Fig. (5). ISSR amplification patterns obtained using six primers in 1.5\% agarose gel electrophoreses. (M) referred to molecular marker size of 100bp DNA ladder, (1 to 13) samples from bread wheat genotypes (Triticum aestivum L.).

Egyptian J. Desert Res., 71, No. 1, 23-52 (2021) 
Table (7). The banding pattern and polymorphism generated by the six ISSR primers for thirteen bread wheat genotypes.

\begin{tabular}{|c|c|c|c|c|c|c|c|c|}
\hline $\begin{array}{l}\text { Primer } \\
\text { Name }\end{array}$ & $\begin{array}{l}\text { Range of } \\
\text { smaller- } \\
\text { larger } \\
\text { (bp) }\end{array}$ & $\begin{array}{c}\text { Mono- } \\
\text { morphic } \\
\text { bands }\end{array}$ & $\begin{array}{l}\text { Polymorphic } \\
\text { (without } \\
\text { unique) }\end{array}$ & $\begin{array}{l}\text { Unique } \\
\text { bands }\end{array}$ & $\begin{array}{l}\text { Polymorphic } \\
\text { (with unique) }\end{array}$ & $\begin{array}{l}\text { Total no. } \\
\text { of bands }\end{array}$ & $\begin{array}{c}\text { Polymorphism } \\
\text { (\%) }\end{array}$ & $\begin{array}{c}\text { Mean } \\
\text { of band } \\
\text { frequency }\end{array}$ \\
\hline $\begin{array}{l}\text { ISSR- } \\
2\end{array}$ & $130-1500$ & 2 & 21 & 1 & 22 & 24 & $92 \%$ & 0.4 \\
\hline $\begin{array}{l}\text { ISSR- } \\
8\end{array}$ & $180-1250$ & 5 & 13 & 4 & 17 & 22 & $77 \%$ & 0.5 \\
\hline $\begin{array}{l}\text { ISSR- } \\
10\end{array}$ & $210-680$ & 10 & 2 & 2 & 4 & 14 & $29 \%$ & 0.8 \\
\hline $\begin{array}{l}\text { ISSR- } \\
11\end{array}$ & $160-1400$ & 3 & 14 & 2 & 16 & 19 & $84 \%$ & 0.5 \\
\hline $\begin{array}{l}\text { ISSR- } \\
13\end{array}$ & $150-1400$ & 2 & 7 & 6 & 13 & 15 & $87 \%$ & 0.4 \\
\hline $\begin{array}{c}\text { ISSR- } \\
14\end{array}$ & $720-2000$ & 6 & 5 & 0 & 5 & 11 & $45 \%$ & 0.7 \\
\hline \multicolumn{2}{|l|}{ Total } & 28 & 62 & 15 & 77 & 105 & -- & 3.3 \\
\hline \multicolumn{2}{|c|}{ Mean per primer } & 4.6 & 10.3 & -- & 12.8 & 17.5 & $69 \%$ & 0.55 \\
\hline
\end{tabular}

The similarity matrix (similarity coefficient of Jaccard) showed that the highest similarity percentage (0.91) was obtained between G10 and G11. While the lowest similarity percentage $(0.63)$ was obtained between G3 and G9 as well as between G1 and G13 with an average genetic similarity coefficient (GS) is 0.77 (Table 8). The dendrogram was constructed using the Unweighted Pair Group Method with Arithmetic Mean (UPGMA) similarity matrix. The cluster analysis was performed using similarity coefficients of Jaccard to study the genetic relations among the genotypes (Fig. 6). The constructed dendrogram divided the genotypes into two main cluster groups: the genotypes G1, G2 and G3 separated from the other ten genotypes which were divided also into two main sub-clusters one included G4, G6, G8 and G7 and the other contained G5, G9, G10, G11, G12 and G13. These findings indicated that using cluster analysis is useful for distinguishing salt-tolerant genotypes apart from the sensitive ones. Furthermore, analysis of DNA using ISSR-PCR provided excellent markers to test genetic variation which successfully was used to classify genetic relationships among genotypes. In this regard, El-Sayed and Ibrahim (2008) estimated genetic diversity among ten double haploid genotypes and five bread wheat varieties were evaluated in salt-affected soil using ISSR marker. They reported that ISSR using four separate primers showed 31 polymorphic fragments with $58.4 \%$ polymorphism from a total of 56 amplified fragments. Four wheat genotypes identified 22 different markers with $41 \%$ polymorphism for salinity tolerance. 
In the current study $65.5 \%$ polymorphism among thirteen genotypes was detected which indicates a good source of diversity could help breeders to develop potentially salt-tolerant genotypes.

Table (8). Genetic similarity (Jaccard's) among the thirteen bread wheat genotypes generated by six ISSR primers

\begin{tabular}{|c|c|c|c|c|c|c|c|c|c|c|c|c|c|}
\hline \multirow{2}{*}{ MW } & \multicolumn{13}{|c|}{ Genotypes } \\
\hline & G1 & G2 & G3 & G4 & G5 & G6 & G7 & G8 & G9 & G10 & G11 & G12 & G13 \\
\hline $\begin{array}{l}1 \\
2\end{array}$ & $\begin{array}{c}100 \\
80\end{array}$ & 100 & & & & & & & & & & & \\
\hline 3 & 70 & 70 & 100 & & & & & & & & & & \\
\hline 4 & 68 & 68 & 67 & 100 & & & & & & & & & \\
\hline 5 & 70 & 68 & 68 & 71 & 100 & & & & & & & & \\
\hline 6 & 71 & 69 & 68 & 79 & 78 & 100 & & & & & & & \\
\hline 7 & 71 & 76 & 67 & 75 & 72 & 77 & 100 & & & & & & \\
\hline 8 & 67 & 72 & 72 & 77 & 70 & 81 & 75 & 100 & & & & & \\
\hline 9 & 72 & 67 & 63 & 73 & 75 & 76 & 70 & 70 & 100 & & & & \\
\hline 10 & 73 & 67 & 71 & 78 & 73 & 77 & 68 & 70 & 87 & 100 & & & \\
\hline 11 & 73 & 68 & 66 & 76 & 75 & 77 & 68 & 66 & 85 & 91 & 100 & & \\
\hline 12 & 68 & 68 & 71 & 76 & 75 & 76 & 72 & 68 & 79 & 87 & 87 & 100 & \\
\hline 13 & 63 & 70 & 71 & 79 & 70 & 76 & 67 & 75 & 75 & 84 & 82 & 87 & 100 \\
\hline
\end{tabular}

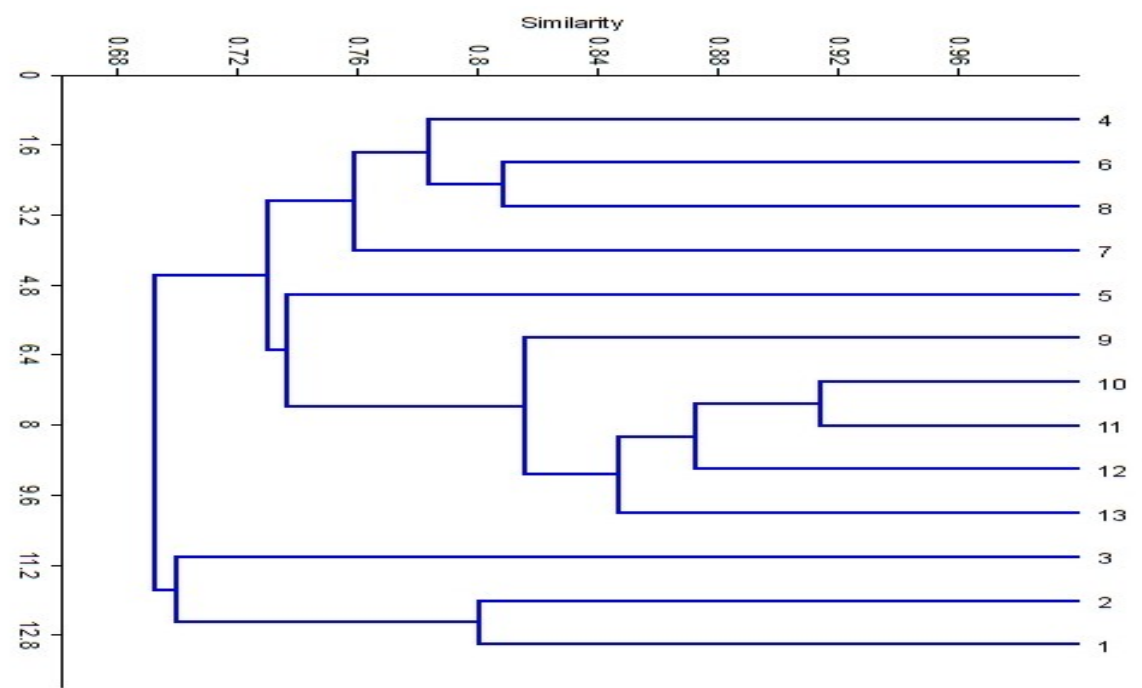

Fig. (6). Dendrogram cluster tree generated by using classify UPGMA cluster analysis based on Jaccard's similarity coefficients obtained from ISSR primers with, for the thirteen bread wheat genotypes.

Egyptian J. Desert Res., 71, No. 1, 23-52 (2021) 


\section{Electrophoresis of Protein}

Data presented in Fig. (7) and Table (9) showed that number of bands in the thirteen wheat breeding lines ranged from 11 to 14 with molecular weights ranged between 6 to $130 \mathrm{kDa}$ under salinity stress conditions. The highest intensive bands are presented at molecular masses 25, 29 and $38 \mathrm{kDa}$ for all thirteen lines. Bands of molecular masses 6, 7, 12, 15, 25, 38, 50, 60, 82 and $130 \mathrm{kDa}$ appeared in all genotypes. In contrast, the band of molecular weight $8 \mathrm{kDa}$ was absent in G1, G2 and G10; and the band of molecular weight $10 \mathrm{kDa}$ was also absent in G9 and G10. In the same trend, the band of molecular weight $18 \mathrm{kDa}$ disappeared G3, G7 and G12. But a unique band of molecular weight $17 \mathrm{kDa}$ appeared only in G3 and also the same effect was observed with a unique band with molecular mass of $20 \mathrm{kDa}$ G4. Concerning band intensity, the results showed that increasing band intensity was detected for all genotypes under salinity stress. The highest intensity was recorded in molecular weight of $38 \mathrm{kDa}$ comparing with other weights. However, the highest values were noticed for G9, G11 and G6. In this context, protein accumulation under salinity stress at low molecular weights could be linked to an increase in the synthesis of certain protein sets (new bands) as molecular chaperons. These chaperones are a large mix of proteins that are involved in various cellular functions, including folding/unfolding, macromolecular assembly/disassembly. Keeping proteins in their native state and preventing their aggregation under different stress conditions, helping to synthesis/degrade proteins and targeting their cellular compartments (Boston et al., 1996). They were later interested in various physiological procedures and plant protection under stress conditions (Chen and Shimamoto, 2011).

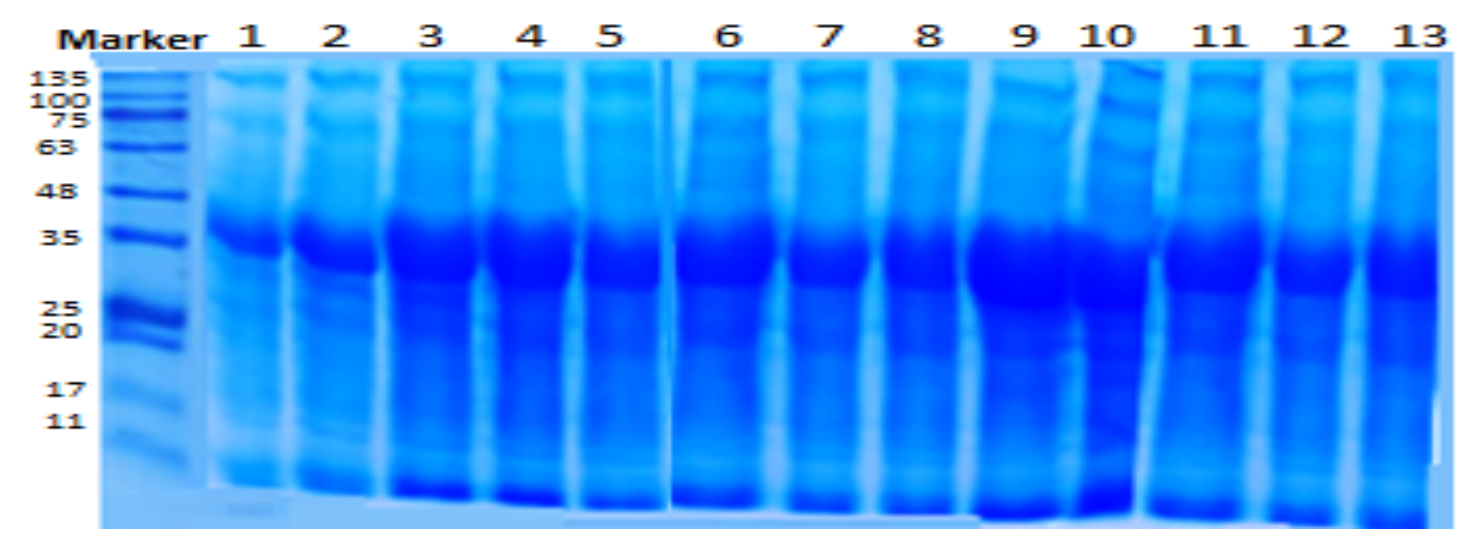

Fig. (7). SDS-PAGE profile (soluble protein) of thirteen wheat genotypes under salinity stress. 


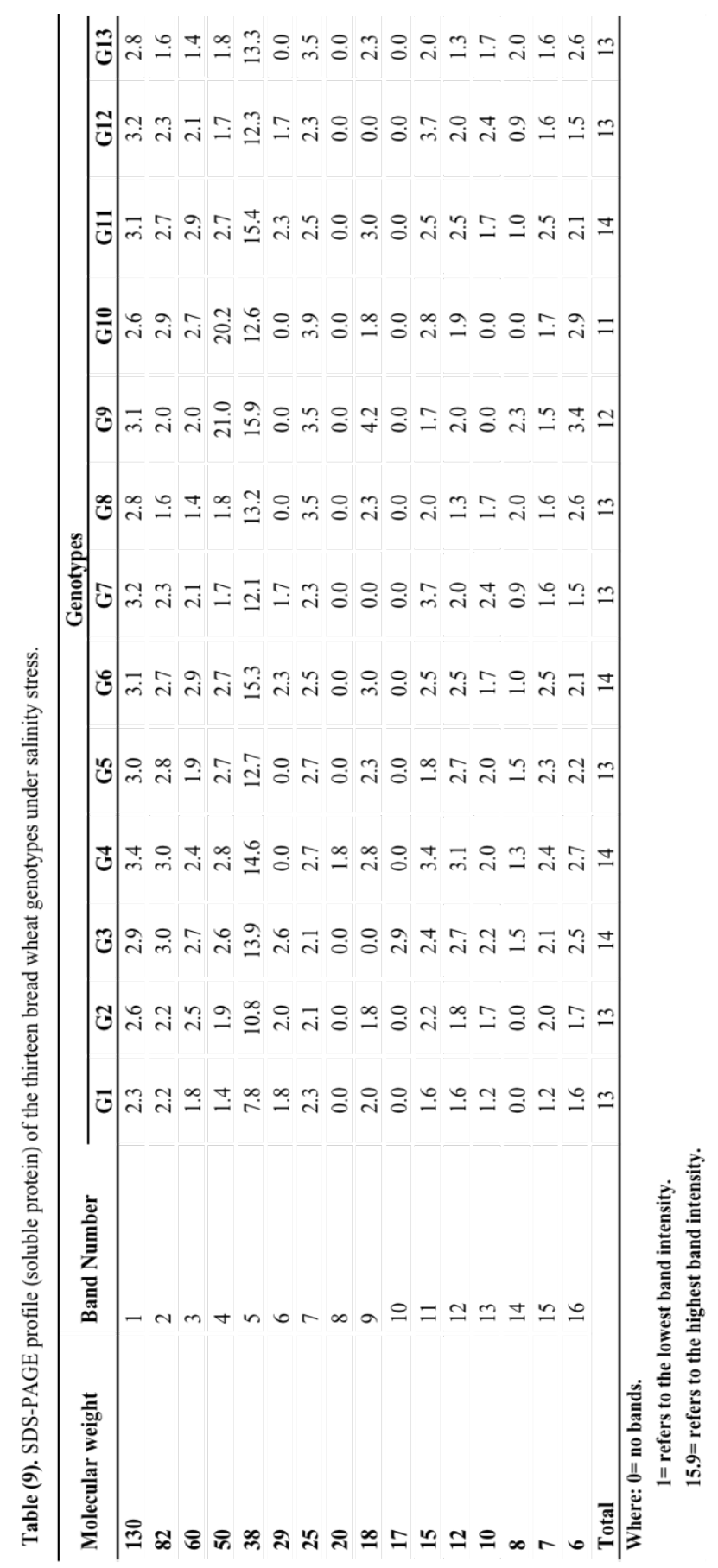

Egyptian J. Desert Res., 71, No. 1, 23-52 (2021) 


\section{Superoxide Dismutase Isozymes}

Superoxide dismutase isozyme (SOD) analysis was performed in the thirteen wheat breeding lines (Fig. 8 and Table 10). The patterns of SOD indicated the presence of 4 bands for all genotypes. The highest intensive bands were presented at band numbers 3 and 4 in all genotypes under salinity stress. While band number 1 was absent in G4, also band number 2 was absent in G3 and G4. However, bands number 3 and 4 were presented in all genotypes. The results displayed that band intensity increased under salinity stress conditions. Comparison of band intensity among genotypes presented that the highest intensity was recorded at band number 4 in genotypes G8, G10 and G9. Regarding band number 3 the maximum value of band intensities was detected in G12, G11 and G13. In this context, plant cells contain a number of antioxidants for reducing or repairing ROS damage and also for controlling redox-sensitive cellular processes. Whereas SOD transforms radical superoxide into hydrogen peroxide and molecular oxygen (Weydert and Cullen, 2010). Furthermore, SOD isoforms often respond differentially to various environmental stresses (Mauro et al., 2005) indicating the importance of qualitative nature of SOD system in the scavenging of superoxide radicals (Guan and Scandalios, 1998).

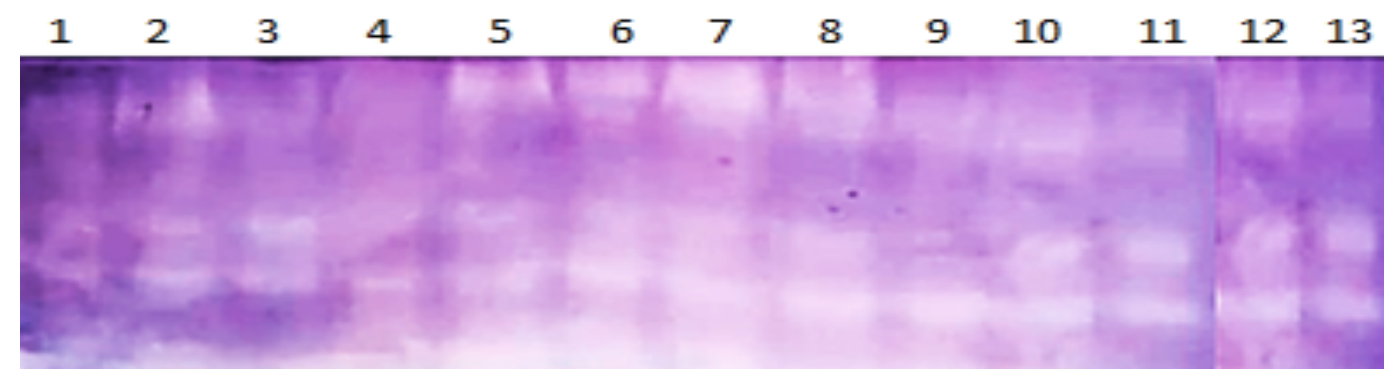

Figure (8). Zymogram of SOD banding pattern isozyme of thirteen wheat genotypes under salinity stress.

Table (10). SOD profile of the thirteen bread wheat genotypes under salinity stress.

\begin{tabular}{lcccccccccccccc}
\hline Band & \multicolumn{10}{c}{ Genotypes } \\
\cline { 2 - 14 } No. & G1 & G2 & G3 & G4 & G5 & G6 & G7 & G8 & G9 & G10 & G11 & G12 & G13 \\
\hline 1 & 1.00 & 2.06 & 1.94 & 0.00 & 1.98 & 2.06 & 3.16 & 2.7 & 2.4 & 1.9 & 1.8 & 1.8 & 1.0 \\
2 & 1.07 & 1.44 & 0.00 & 0.00 & 1.23 & 1.19 & 1.36 & 2.5 & 1.7 & 2.0 & 2.7 & 1.7 & 2.1 \\
3 & 1.42 & 1.36 & 1.63 & 1.12 & 1.24 & 1.14 & 1.37 & 3.4 & 3.0 & 3.6 & 3.9 & 4.2 & 3.8 \\
4 & 1.38 & 1.55 & 2.30 & 2.04 & 2.44 & 3.08 & 3.18 & 4.5 & 4.0 & 4.3 & 3.4 & 3.9 & 3.9 \\
Total & 3 & 3 & 2 & 1 & 4 & 4 & 4 & 4 & 4 & 4 & 4 & 4 & 4 \\
\hline
\end{tabular}

Where: $0=$ no bands, $1.00=$ refers to the lowest band intensity, $4.5=$ refers to the highest band intensity. 


\section{REFERENCES}

Abbas, S., A. Muhammad, Z. Nawal, U.B. Mazhav, N. Allah, M. Aqib, D.K. Muhammad and M. Muhammad (2018). Investigating the difference of salt tolerance determinants in contrasting bread wheat (Triticum aestivum L.). Rnd. J., 2 (1): 69-92.

Abd El-Mohsen, A.A., M.A. Abd El-Shafi, E.M.S. Gheith and H.S. Suleiman (2015). Using different statistical procedures for evaluating drought tolerance indices of bread wheat genotypes. Adv. Agric. Biol., 4 (1): 19-30.

Abdel-Ghani, A.H. (2013). Selection of high yielding lines from heterogeneous Jordanian barley landraces under well watered and drought stress conditions. Bull. Fac. Agric., Cairo Univ., 64:13-29.

Afiah, S.A., W.A. Hassan and N.A.K. Rashed (2016). Selecting salinity tolerant bread wheat genotypes under Ras-Sudr and middle Delta conditions, Egypt. J. Plant Breed., 20 (6): 929-952.

Ahmadi, G., A. Akbarabadi, D. Kahrizi, A. Rezaizad and M. Gheytouli (2012). Study of drought tolerance of bread wheat (Triticum aestivum L.) genotypes in seedling stage. Biharean Biol., 6 (2): 7780.

Ajmal, S.A., N. Zakir and M.Y. Mujahid (2009). Estimation of genetic parameters and character association in wheat. J. Agric. Biol. Sci., 1 (1): $15-18$.

Akcura, M. and S. Ceri (2011). Evaluation of drought tolerance indices for selection of Turkish oat (Avina sativa L.) landraces under various environmental conditions. Zemdirbyste $=$ Agriculture, 98 (2): 157166.

Akcura, M., F. Partigoc and Y. Kaya (2011). Evaluation of drought stress tolerance based on selection indices in Turkish bread wheat landraces. J. Anim. Plant Sci., 21 (4): 700-709.

Ali, F. (2003). Heritability and genetic advance of grain yield and its related traits in wheat. Pakistan J. Biol. Sci., 6 (4): 2020-2023.

Al-Naggar, A.M.M., S.R.S. Sabry, M.M.M. Atta and O.M. Abd-Aleem (2015). Effects of salinity on performance, heritability, selection gain and correlations in wheat (Triticum aestivum L.) doubled haploids. Sci. Agri., 10 (2): 70-83.

Al-Naggar, A.M.M., M.A. Abd El-Shafi, M.H. El-Shal and A.H. Anany (2020). Selection criteria and selection environment for drought tolerance of Egyptian wheat (Triticum aestivum L.) landraces. Annu. Res. Rev. Biol., 35 (2): 25-40.

Asadi, M., N.G. Mohammadi, P. Golkar, H. Naghavi and B. Nakhoda (2012). Assessment of salinity tolerance of different promising lines of

Egyptian J. Desert Res., 71, No. 1, 23-52 (2021) 
bread wheat (Triticum aestivum L.). Adv. Appl. Sci. Res., 3 (2): 1117-1121.

Asgari, H.R., W. Cornelis and P. Van Damme (2011). Effect of salinity on wheat (Triticum aestivum L.) grain yield, yield components and ion uptake. Desert, 16 (1): 169-175.

Awaad, H.A., M.A.H. Youssef and E.S.A. Moustafa (2010). Identification of genetic variation among bread wheat genotypes for lead tolerance using morpho-phsiological and molecular markers. J. Am. Sci., 6 (10): 1142-1153.

Badran, A.E. and E.S.A. Moustafa (2014). Drought resistance indices and path analysis in some wheat genotypes. World Applied Sciences Journal, 30 (12): 1870-1876.

Bagci, S.A., H.E. Kiz and A. Yilmaz (2007). Salt tolerance of six teen wheat genotypes during seedling growth. Turk. Agric., 31 (3): 363-372.

Balkan, A. (2018). Genetic variability, heritability and genetic advance for yield and quality traits in $\mathrm{M}_{2-4}$ generations of bread wheat (Triticumaestivum L.) genotypes. Turk. J. Field Crops, 23 (2): 173179.

Bayisa, T., H. Tefera and T. Letta (2020). Genetic variability, heritability and genetic advance among bread wheat genotypes at Southeastern Ethiopia. Agriculture, Forestry and Fisheries, 9 (4): 128-134.

Bockelman, H.E., J. Valkoun and S. Ullrich (2010). In: "Barley Germplasm Conservation and Resources". Wiley-Blackwell: Oxford, UK.

Boston, R.S., P.V. Viitanen and E. Vierling (1996). Molecular chaperones and protein folding in plants. Plant Molecular Biology, 32: 191-222.

Bouslamam M. and N.T. Schapaugh (1984). Stress tolerance in soybean. Part 1: Evaluation of three screening techniques for heat and drought tolerance. Crop Sci., 24: 933-937.

Chen, L. and K. Shimamoto (2011). Emerging roles of molecular chaperones in plant innate immunity. Journal of General Plant Pathology, 77: 19.

Cosgrove, W.J. and F.R. Rijsberman (2000). In: "World Water Vision". Earthscan Publications, London.

Darwish, M.A.H., M. Fares and E.M.A. Hussein (2017). Evaluation of some bread wheat genotypes under saline soil conditions using tolerance indices and multivariate analysis. J. Plant Prod., Mansoura Univ., 8 (12): 1383-1394.

Desheva, G. and B. Kyasov (2015). Genetic diversity assessment of common winter wheat (Triticum aestivum L.) genotypes. Emir. J. Food Agric., 27 (3): 283-290.

El-Hendawy, S.E., Y. Hu, J.I. Sakagami and U. Schmidhalter (2011). Screening Egyptian wheat genotypes for salt tolerance at early

Egyptian J. Desert Res., 71, No. 1, 23-52 (2021) 
growth stages. International Journal of Plant Production, 5 (3): 283298.

El-Sayed, O.E. and H.F. Ibrahim (2008). Development of RAPD and ISSR markers associated with salt tolerance in bread wheat using in vitro culture. Middle Eastern and Russian Journal of Plant Science and Biotechnology, 2: 52-59.

FAO (2008). FAO land and plant nutrition management service. Available online: http://www.Fao.org/ag/agl/agll/spush.

FAOSTAT (2018). Food and Agriculture Organization of the United Nations of Statistical database (Accessed 5 march, 2018).

Ferede, M. and F. Worede (2020). Variability, heritability and genetic advance analysis in bread wheat (Triticum aestivum L.) genotypes in Northwestern Ethiopia. Int. J. Sustain. Agri. Res., 7 (2): 56-65.

Fernandez, G.C.J. (1992). Effective selection criteria for assessing stress tolerance. Proceedings of the International Symposium on Adaptation of Vegetables and Other Food Crops in Temperature and Water Stress. Taiwan, pp. 257-270.

Firouzian, A. (2003). Heritability and genetic advance of grain yield and its related traits in wheat. Pakistan Journal of Biological Science, 6 (24): 45-51.

Firozi, B., O. Sofalian, M. Shokrpour, A. Rasolzadeh and F. Ahmadpoor (2012). Assessment of drought tolerance indices and their relation with ISSR markers in bread wheat (Triticum aestivum L.), Not. Sci. Biol., 4 (3): 143-150.

Fischer, R.A. and R. Maurer (1978). Drought resistance in spring wheat cultivars. 1. Grain yield response. Australian J. Agric. Res., 29: 897912.

Gadimaliyeva, G., Z. Akparov, N. Aminov, A. Aliyeva, J. Ojaghi, S. Salayeva, M. Serpoush, A. Mammadov and A. Morgounov (2020). Assessment of synthetic wheat lines for soil salinity tolerance. Zemdirbyste Agric., 107 (1): 55-62.

Gavuzzi, P., F. Rizza, M. Palumbo, R.G. Campaline, G.L. Ricciardi and B. Borghi (1997). Evaluation of field and laboratory predictors of drought and heat tolerance in winter cereals. Canadian J. Plant Sci., 77: 523-531.

Golabadi, M., A. Arzani and S.A.L. Mirmohammadi Maibody (2006). Assessment of drought tolerance in segregating populations in durum wheat. Afri. Agri. J. Res., 1: 163-171.

Gonzalez, A., I. Martin and L. Ayerbe (1999). Barley yield in water-stress condition. The influence of precocity, osmotic adjustment and stomatal conductance. Field Crop Res., 62: 23-34.

Egyptian J. Desert Res., 71, No. 1, 23-52 (2021) 
Guan, L. and J.G. Scandalios (1998). Two structurally similar maize cytosolic superoxide dismutase genes, Sod4 and Sod4A, respond differentially to abscisic acid and high osmoticum. Plant Physiology, 117: 217-224.

Hanson, H., N.E. Borlaug and R.G. Anderson (1982). In: "Wheat in the Third World". Boulder Colorado: West View Press, 562 p.

Hawkes, J.G. (1983). In: “The diversity of Crop Plants". Harvard University Press, Cambridge, London, England, pp. 164-177.

Horsley, R.D., P.B. Schwarz and J.J. Hammond (1995). Genetic diversity in malt quality of North American 6-rowed spring barley. Crop Sci., 35 (1):113-118.

Huang, B. (2000). Role of Root Morphological and Physiological Characteristics in Drought Resistance of Plants. In: "Wilkinson, R.E. (Ed.)", Plant-Environment Interactions. Marcel Dekker Inc., New York, pp. 39-64.

Ilyas-Khokhar, M., A.J. Teixeira da Silva and H. Spiertz (2012). Evaluation of barley genotypes for yielding stability and drought tolerance under irrigated and water-stressed conditions. Am. Eurasian J. Agric. Environ. Sci., 12 (3): 287-292.

Jafari, A.A., F. Paknejad and M. Jamial-Ahmadi (2009). Evaluation of selection indices for drought tolerance in corn (Zea mays L.) hybrids. Int. J. Plant. Prot., 3: 33-38.

Jaur, S.C. (2019). Genetic improvement through variability, heritability and genetic advance for grain yield and its contributing traits in wheat (Triticum aestivum L. em Thell). Int. J. Pure App. Biosci., 7 (1): 368373.

Johnson, H.W., H.F. Robinson and R.E. Comstock (1955). Estimates of genetic and environmental variability in soybean. Agron. J., 47: 314318.

Kahrizi, D., K. Cheghamirza, M. Kakael, R. Mohammadi and A. Ebadi (2010). Heritability and genetic gain of some morpho-physiological variables of durum wheat (Triticum turgidum var. durum). African Journal of Biotechnology, 9 (30): 4687-4691.

Kashif, M., J. Ahmad, M.E. Chowdhry and K. Perveen (2003). Study of genetic architecture of some important agronomic rates in durum wheat (Triticum durum Desf.). Asian J. Plant Sci., 2: 708-712.

Khalili, M., M. Kazemi, A. Moghaddam and M. Shakiba (2004). Evaluation of drought tolerance indices at different growth stages of latematuring corn genotypes. Proceedings of the $8^{\text {th }}$ Iranian Congress of Crop Science and Breeding, Aug. 25-27, Rasht, Iran, pp. 298-208.

Khanzada, R., M.A. Siyal, S. Bano, S. Syed, S. Arain, S. Nazeer and M.K. Soothar (2019). Heritability estimates in F4 generation of wheat 
(Triticum aestivum L.) under the agro-climatic condition of Tandojan, Sindh-Pakistan. Pure Appl. Biol., 8 (2): 1240-1253.

Kumar, B., G.M.L. Ruchi and A. Upadhyay (2009). Genetic variability, diversity and association of quantitative traits with grain yield in bread wheat (Triticum aestivumL.). Asian J. Agric. Sci., 1 (1): 4-6.

Laemmli, U.K. (1970). Cleavage of structural proteins during the assembly of the head of bacteriophage T4. Nature, 227: 680-685.

Limin, A., A. Corey, P. Hayes and D.B. Fowler (2007). Low-temperature acclimation of barley cultivars used as parents in mapping population: response to photoperiod, vernalization and phonological development. Planta, 226: 139-146.

Lydansky, T. (1988). In "Statistical Methods in Biology and Agriculture". Sofia: Zemizdat.

Maha, A., S. Gadiallah, I. Sanaa, M. Milad, Y.A. Amira, Y. Abo Yossef and M.A. Gouda (2017). Evaluation of some Egyptian bread wheat (Triticum aestivum L.) cultivars under salinity stress. Alexandria Science Exchange Journal, 38 (2): 259-270.

Manal, H.E. (2009). Estimation of heritability and genetic advance of yield traits in wheat (Triticum aestivum L.) under drought condition. Int. J. Genet. Mol., 1 (7): 115-120.

Maniee, M., D. Kahrtizi and R. Mohammadi (2009). Genetic variability of some morpho-physiological traits in durum wheat (Triticum turgidum var. durum). J. Appl. Sci., 9 (7): 1383-1387.

Mansour, E., E.S. Moustafa, E.S.M. Desoky, M. Ali, M.A. Yasin, A. Attia, N. Alsuhaibani, M.U. Tahir and S. El-Hendawy (2020): Multidimensional evaluation for detecting salt tolerance of bread wheat genotypes under actual saline field growing conditions. Plants, 9: Article 1324.

Maryam, A., N.G. Mohammadi, P. Golkar, H. Naghavi and B. Nakhoda (2012). Assessment of salinity tolerance of different promising lines of bread wheat (Triticum aestivum L.). Adv. Appl. Sci. Res., 3 (2): 1117-1121.

Mauro, S., F. Van Eycken, N. Challou, P. Lucas and M.L. Oiseau (2005). Characterization of new maize chloroplastic copper/zinc superoxide dismutase isoforms by high resolution native two-dimensional polyacrylamide gel electrophoresis. Identification of chilling responsive chloroplastic superoxide dismutase isoforms. Physiologia Plantarum, 124: 323-335.

Mishra, U., A.K. Sharma and S. Chauhan (2019). Genetic variability, heritability and genetic advance in bread wheat (Triticum aestivum L.). Int. J. Curr. Microbiol. App. Sci., 8 (7): 2311-2315.

Egyptian J. Desert Res., 71, No. 1, 23-52 (2021) 
Mitra, J. (2001). Genetics and genetic improvement of drought resistance in crop plant. Curr. Sci., 80: 758-762.

Moghaddam, A. and M.H. Hadi-Zadeh (2002). Response of corn (Zea-mays L.) hybrids and their parental lines to drought using different stress tolerance indices. Iranian Journal of Seed and Seedling, 18 (3): 255272.

Mohamed, A.A., B. Eichler-Lobermann and E. Schnug (2007). Response of crops to salinity under Egyptian conditions: a review. Landbaurorschnug Volkenrode, 2 (57): 119-125.

Munns, R. (2005). Genes and salt tolerance: bringing them together. New Phytol., 167: 645-663.

Nizamani, M.M., F.G. Nizamani, R.A. Rind, A.A. Khokhar, A. Mehmood and M. Nizamani (2020). Heritability and genetic variability estimates in F3 populations of bread wheat (Triticum aestivum L.). Pure Appl. Biol., 9 (1): 252-368.

Rahman, U.S. and F. Subhan (2010). Genetic gain for grain yield in two selection phases of a wheat breeding program. Pak. J. Bot., 42 (3): 1595-1600.

Ravari, S.Z., H. Dehgham and H. Naghavi (2017). Study of genetic control of salinity tolerance in bread wheat cv. Kavir-using generation mean analysis. Crop Breeding Journal, 7 (182): 57-66.

Rosielle, A.A. and J. Hamblin (1981). Theoretical aspects of selection for yield in stress and non-stress environments. Crop Sci., 21: 943-946

Saidi, A., A. Akbari, J. Mozzaffari, A. Heidari, M. SerjaAzari, B. Piryeshfar, A. Yazdansepas, S.N. Salim and M.C. Saxina (2000). Adaptation of spring-sown chickpea to Mediterranean basin. 2. Factors influencing yield under drought. Field Crop Res., 34: 137-146.

Salah, E.E., H.U. Yuncai, M.Y. Gamal, M.A. Ahmed, H. Salah and S. Urs (2005). Evaluating salt tolerance of wheat genotypes using multiple parameters. Europ. J. Agron., 22 (1): 242-253.

Sanjay, S., R.S. Sengar, K. Neeraj, D. Datta, R.S. Tomar, V.P. Rao, G. Deepa and O. Ashish (2015). Assessment of multiple tolerance indices for salinity stress in bread wheat (Triticum aestivum L.). J. Agri. Sci., 7 (3): 49-57.

Sara, Z.M., A. Yasin, M. Niaz, K. Abida and H. Jafar (2015). Evaluation of wheat genotypes for salinity tolerance using physiological indices as screening tool. Pak. J. Bot., 47 (2): 397-405.

Shah, A.A., R.A. Bhat, B.A. Bhat and S.K. Mondal (2019). Genetic evaluation of winter wheat genotypes under rainfed conditions. International Journal of Chemical Studies, 7 (1): 1064-1071. 
Shao, H.B., L.Y. Chu, Z.H. Lu and C.M. Chang (2007). Primary antioxidant free radical scavenging and redox signaling pathways in higher plant cells. Int. J. Biol. Sci., 4: 8-14.

Shavrukov, Y., A. Kurishbayev, S. Jatayev, V. Shvidcheno, L. Zotova, F. Koekemoer, S. de Groot, K. Soole and P. Langridge (2017). Early flowering as a drought escape mechanism in plants: how can aid wheat production? Front. Plant Sci., 8: 1950: 1-8.

Singh, R.K. and B.D. Chaudhary (1985). In: "Biometrical Methods in Quantitative Genetic Analysis". Kalyani Publ., New Delhi.

Sneath, P.H.A. and R.R. Sokal (1973). In: "Numerical Taxonomy: The Principles and Practice of Numerical Classification". San Francisco: Freeman, $573 \mathrm{pp}$.

Sonia, K., S. Mohammad and S. Omid (2013). Evaluation of the effect of salt stress on some of agronomic and morphological characters in ten durum wheat cultivars. Annals of West University of Timisoara, Ser. Biol., 7 (1): 19-24.

SPSS Inc. (2007). SPSS for windows. Release 16.0. SPSS Inc. Chicago, IL. USA.

St. Martin, S.K. and B.A. McClain (1991). Procedure to estimate genetic gain by stages in multistage testing programs. Crop Sci., 31: 1367-1369.

Turan, S. and B.C. Tripathy (2012). Salt and genotype impact on antioxidative enzymes and lipid peroxidation in two rice cultivars during de-etiolation. Protoplasma. 250: 209-222.

Turan, S., K. Coresh and S. Kumar (2012). Salinity tolerance in plants: breeding and genetic engineering. Australian J. Cro. Sci., 6 (9): 1337-1348.

Unesco Water Portal (2005). Available online: http:www.unesco.org/water

USDA-ARS (2008). Research Databases. Bibliography on Salt Tolerance. In "George, E. and Jr. Brown eds.". Salinity Lab. US Dep. Agric., Agric. Res. Serv. Riverside, CA. Available online: http://www.ars. usda.gov/Services/docs. Htm?docid=8908.

Varshney, R.K., K.C. Bansal, P.K. Aggarwal, S.K. Datta and P.Q. Craufurd (2011). Agriculture biotechnology for crop improvement in a variable climate: hope or hype? Trends Plan. Sci., 16: 363-371.

Weydert, C.J. and J.J. Cullen (2010). Measurement of superoxide dismutase, catalase and glutathione peroxidase in cultured cells and tissue. Nature Protocols, 5: 51-66.

Yassien, H.E., E.I. Zaazaa, I.M. Al-Ashkar and M.N. Khamees (2016). Breeding for salt tolerance in bread wheat (Triticum aestivum L.). Al-Azhar J. Agric. Res., 27 (1): 297-309.

Yassin, M., A. El-Sabagh, A.M.M. Mekawy, M.S. Islam, A. Hossain, G. Barutcular, H. Al Harby, A. Bamagoos, L. Liu, A. Ueda and H.

Egyptian J. Desert Res., 71, No. 1, 23-52 (2021) 
Saneoka (2019). Comparative performance of two bread wheat (Triticum aestivum L.) genotypes under salinity stress. Applied Ecology and Environmental Research, 17 (2): 5029-5041.

Egyptian J. Desert Res., 71, No. 1, 23-52 (2021) 


\title{
تقييم سلالات متقدمة من القمح تحت ظروف الملوحة بإستخدام دلائل التحمل
}

\author{
إيهاب سعودي عبد الحميد مصطقى \\ وحدة تربية النبات، قسم الأصول الور اثية إثلة، مركز بحوث الصحر اء، المطرية، القاهرة،
}

ركزت هذه الدراسة على مقارنة السلوك الور اثي لثلاثة عشر سلالة منقدمة من القمح مقارنة

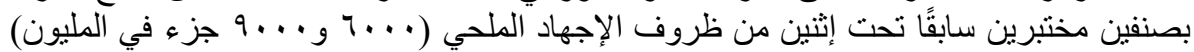

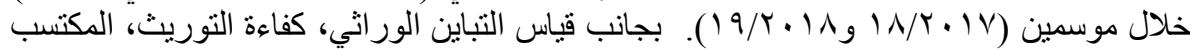

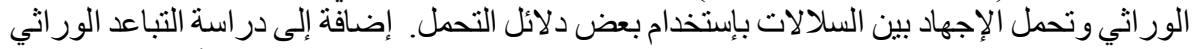

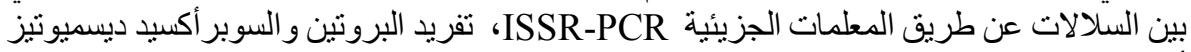

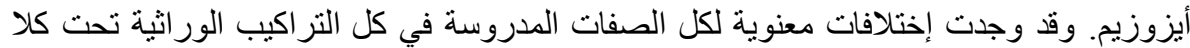

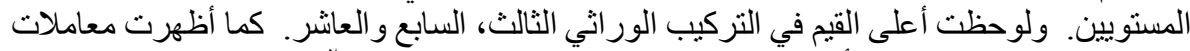

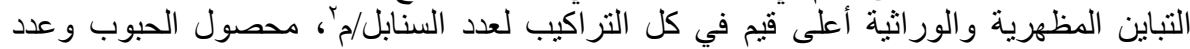

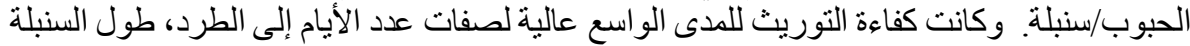

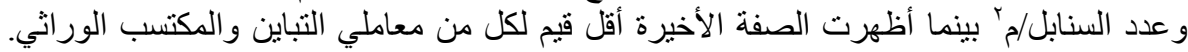

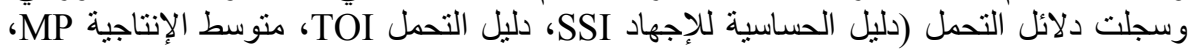

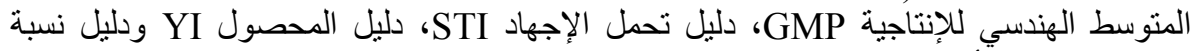

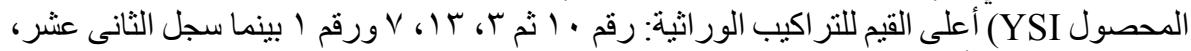

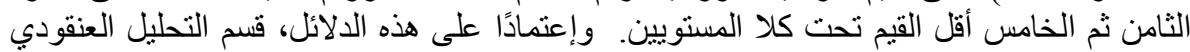

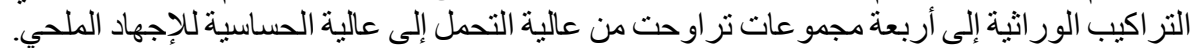

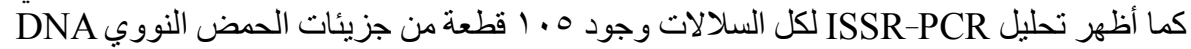

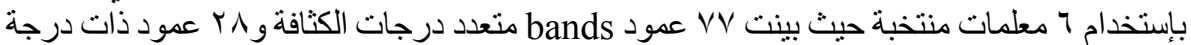

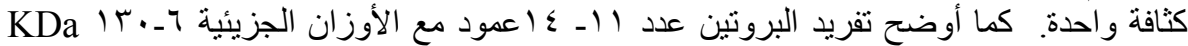

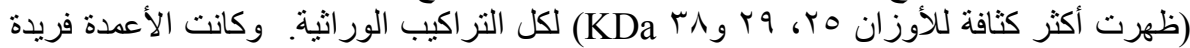

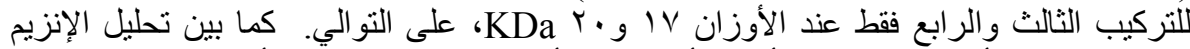

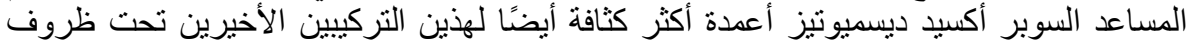

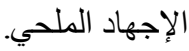

Egyptian J. Desert Res., 71, No. 1, 23-52 (2021) 